\title{
Лікування хворих із донорськими ранами, що тривалий час не загоюються
}

\begin{abstract}
Мета роботи: обгрунтувати ефективність ін’єкційного застосування плазми, збагаченої тромбоцитами при лікуванні ран донорської поверхні, що тривалий час не загоюються у хворих із глибокими термічними опіками.

Матеріали і методи. У дослідженні взяли участь 15 пацієнтів з опіками полум’ям II ${ }^{6}-$ III ступеня, площею 10-15 \% поверхні тіла. Від початку з $(27,3 \pm 0,1)$ доби після отримання травми залежно від обраного місцевого лікування пацієнтів поділили на дві групи. У 5 пацієнтів основної групи перев’язки, окрім обробки ранової поверхні 0,02 \% розчином декаметоксину, передбачали щоденне впродовж 6-7 діб ін'єкційне введення автологічної плазми, збагаченої тромбоцитами, по периферії та безпосередньо в ділянку донорських ран. Залишок препарату аплікаційно наносили на рановий дефект, який покривали двошаровою марлевою серветкою, просякнутою однойменним антисептиком і полівінілхлоридною плівкою з фіксацією лейкопластерними стрічками, марлевою пов'язкою. У 10 пацієнтів групи порівняння місцеве лікування донорських ран обмежувалось перев’язками з використанням цього ж антисептичного розчину.

Обстеження хворих передбачало візуальний огляд ушкодженої ділянки, визначення площі ранового дефекту, мікробіологічне та цитологічне дослідження ранового вмісту.

Результати досліджень та їх обговорення. Результати дослідження показали позитивний ефект застосування автологічної плазми, збагаченої тромбоцитами, уже на 3 добу спостереження, що проявлялось зміною кольору, структури грануляційної тканини в кращий бік, активним перебігом процесів епітелізації у вигляді появи острівців на поверхні рани та росту з країв, наближенням цитологічної картини до запально-регенераторного типу. В подальшому в пацієнтів основної групи визначали

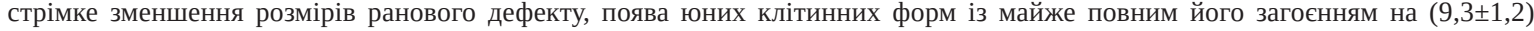
добу після початку введення плазми. Лікування хворих групи порівняння традиційним способом завершувалось виконанням автодермопластики.
\end{abstract}

Ключові слова: опіки; донорські рани; ускладнення; плазма, збагачена тромбоцитами; автодермопластика.

Постановка проблеми і аналіз останніх досліджень та публікацій. Опіки залишаються актуальною проблемою медицини, де все більше переважають пацієнти з поширеними та глибокими травмами [1]. Одним із шляхів вирішення цієї ситуації $є$ пошук нових та удосконалення існуючих підходів надання допомоги 3 подібними травмами. Впровадження технології раннього адекватного хірургічного видалення некротизованих тканин дало можливість відчутно покращити результати лікування хворих з тяжкими опіками скоротивши терміни перебування їх у стаціонарах та ризики виникнення ускладнень, в тому числі летальних. Разом із тим, виникла необхідність швидкого закриття післяопераційних ран, особливо в умовах дефіциту донорських ресурсів, який з’являється при глибокому термічному ушкодженні площею понад 15 \% поверхні тіла [2]. Тривале загоєння ран донорської поверхні, яке подекуди досягає майже 30 \%, часто призводить до формування гіпертрофічних і келоїдних рубців із депігментацією, вторинними деформаціями [3]. Подібний стан $є$ особливо загрозливим для хворих із критичними опіками, оскільки погіршує перебіг опікової хвороби в післяопераційному періоді і відтерміновує можливість виконання наступних етапних реконструктивних хірургічних втручань. На думку багатьох вчених, необхідно продовжувати пошук методів стимуляції репаративних процесів у рані, які б сприяли швидшому загоєнню донорських ран, поверхневих опікових ран та скорочували б терміни підготовки глибоких гранулюючих ран до пересадки шкіри. Одним із таких методів є використання автологічної плазми, збагаченої тромбоцитами (АПЗТ) - фракції крові, у якій вміст тромбоцитів значно перевищує вихідний рівень [4]. Встановлено, що в ділянці використання такої плазми за рахунок вивільнення численних біоактивних субстанцій, більшість 3 яких міститься в альфа-гранулах, відбувається стимуляція процесів ангіогенезу, проліферації, диференціювання тканин, синтезу колагену, пригнічуючи при цьому вивільнення цитокінів та прогресування запальної реакції [5]. Таким чином, при використанні АПЗТ відбувається покращення результатів загоєння ран різної етіології і відновлення дефектів тканин. Саме це стало підставою для використання подібної плазми в комплексному лікуванні ускладнених ран донорської поверхні у хворих із термічними опіками. 
Мета роботи: обгрунтувати ефективність ін'єкційного застосування плазми, збагаченої тромбоцитами при лікуванні донорських ран, що тривалий час не загоюються, у хворих з глибокими термічними опіками.

Матеріали і методи. У дослідженні взяли участь 15 хворих з опіками полум'ям II ${ }^{6}-\mathrm{III}$ ступеня, площею 10-15 \% поверхні тіла, які перебували на лікуванні в умовах Клінічного центру термічної травми та пластичної хірургії Комунального некомерційного підприємства "Вінницька обласна клінічна лікарня імені М. І. Пирогова Вінницької обласної Ради” у період 2011-2021 pp. Комплексна терапія хворих передбачала загальне (інфузійно-трансфузійну, антибактеріальну, антикоагулянтну, симптоматичну терапію), місцеве (перев’язки з антимікробними засобами, рановими покриттями) та хірургічне (рання некректомія на 2-3 доби після травми з видаленням девіталізованих та етапне відновлення шкірних покривів АДТ) лікування. Забір трансплантатів завтовшки 0,2-0,4 мм, завширшки 60 мм виконували на передній та зовнішній поверхні стегна електричним дисковим дерматомом ДЕ-60-01. Незважаючи на успішне приживлення понад 80 \% трансплантатів (за оцінкою Петрова В. І.) загоєння ран донорської поверхні тривало понад 26 діб, що виходило за межі допустимого неускладненого репаративного процесу в цій ділянці. Залежно від обраного місцевого лікування донорських ділянок пацієнти були розподілені дві на групи. У 5 пацієнтів основної групи (середній вік - 49,7士4,1 року) перев’язки, окрім обробки ранової поверхні 0,02 \% розчином декаметоксину, передбачали щоденне впродовж 6-7 діб ін'єкційне введення автологічної плазми, збагаченої тромбоцитами, по периферії та безпосередньо в ділянку донорських ран. Залишок препарату аплікаційно наносили на рановий дефект, який покривали двошаровою марлевою серветкою, просякнутою однойменним антисептиком і полівінілхлоридною плівкою з фіксацією лейкопластерними стрічками, марлевою пов’язкою.

У пацієнтів групи порівняння ( $\mathrm{n}=10$; середній вік 48,8 \pm 4,7 року) місцеве лікування донорських ран обмежувалось щоденними перев'язками з використанням вищезгаданого антисептичного розчину.

Для отримання АПЗТ безпосередньо перед застосуванням здійснювали забір 18 мл венозної крові з периферичної вени пристроєм Vacutainer R Flashback (Becton, Dickinson and Company, США), розмір голки 21 G, у пробірку Vacutest R Plast
(Vacutest Kima s.r.l., Італія) місткістю 9 мл з гепарином натрію, вміст якого становив 17 МО/мл, обережно перемішували вміст півколовими обертами 4-5 разів. У подальшому впродовж 15 хв при частоті обертання 2500 об./хв проводили центрифугування крові (центрифуга ELMI CM-6M, Латвія). Після цього у пробірці утворювалося 3 шари: верхній шар плазми світло-жовтого кольору, проміжний шар помутніння та нижній - інтенсивно червоного забарвлення з домінуванням еритроцитів. За допомогою спеціальної піпетки верхній шар забирали і заповнювали інсуліновий шприц, за допомогою якого і проводили безпосереднє введення препарату.

Обстеження хворих передбачало візуальний огляд ушкодженої ділянки на 1, 3, 7, 10, 14 доби, визначення площі ранового дефекту планіметричним методом за допомогою мобільного додатку "LesionMeter" [6]. Мікробіологічне обстеження з виділенням, ідентифікацією та напівкількісним визначенням збудника проводили на 1, 3, 7 доби від початку дослідження. Стерильною марлевою серветкою рану очищали від гнійно-некротичних виділень, ватним тампоном здійснювали забір матеріалу з подальшим його транспортуванням у стерильній пробірці з середовищем Amies до бактеріологічної лабораторії впродовж 2 годин. Висів на поживне середовище та визначення кількісного вмісту бактерій в отриманих зразках клінічного біоматеріалу з поверхні ран проводили за загальновідомою оригінальною методикою [7]. Ідентифікацію збудників проводили за сукупністю морфологічних, культуральних та біохімічних ознак.

Додатково у ці ж терміни виконували цитологічне дослідження ранового вмісту з поверхні рани методом “мазків-відбитків” за М. В. Покровською, М. С. Макаровим в модификації Д. М. Штейнберга [8]. Отримані мазки фарбували азур-еозином за Романовським-Гімзою і досліджували методом світлової мікроскопії. В отриманих зразках мазків-відбитків підрахововували відсоткове співвідношення нейтрофільних гранулоцитів (НГ) та їх дегенеративних форм, лімфоцитів, моноцитів, макрофагів, фібробластів і активність фагоцитозу. Аналіз отриманих цитограм проводили за 6 типами: I тип - некротичний; II тип - деструктивно-запальний; III тип - запальний; IV тип - запально-регенеративний; V тип - регенеративно-запальний; VI тип - регенеративний.

Статистична обробка отриманих результатів була виконана з використанням програмного забезпечення Microsoft Excel 2016 та "STATISTICA 5.5” (належить ЦНІТ ВНМУ імені М. І. Пирогова, ліцензія № AXXR910A374605FA) з визначенням 
середньоарифметичної величини і ї̈ похибки ( $\mathrm{M} \pm$ $\mathrm{m})$, критерія Стьюдента (t) та показника достовірності (р). Достовірними вважали відмінності при $\mathrm{p} \leq 0,05(95,5 \%)$.

Дослідження виконано із дотриманням правил безпеки пацієнтів, збереженням права та законів людської гідності, морально-етичних норм відповідно до основних положень GSP (1996 р.), Конвенції Ради Європи про права людини та біомедицину (від 04.04.1997р.), Гельсінської декларації Всесвітньої медичної асоціації про етичні принципи проведення наукових медичних досліджень за участю людини (1964-2000рр.) і наказу МО3 України № 281 від 01.11.2000 р., етичного кодексу ученого України (2009) та обов’язковою інформованою згодою пацієнтів на участь у дослідженні.

Результати досліджень та їх обговорення. На $(27,3 \pm 0,1)$ добу 3 моменту отримання травми в ділянці донорської поверхні стегна пацієнтів основної групи та групи порівняння визначали залишкові ранові дефекти розміром $(294,5 \pm 7,9) \mathrm{cm}^{2}$ та $(282,7 \pm 9,3)$ см² $^{2}$ відповідно $з$ частковою епітелізацією, яка легко травмувалася. Ранова поверхня була вкрита грануляційною тканиною блідорожевого кольору, в’ялої консистенції, подекуди 3 надлишковим розростанням, визначалися патологічні нашарування та кірочки без вираженого ексудативного компоненту. Оточуючі тканини були набряклі та гіперемійовані. Періодично пацієнтів турбував біль у цих ділянках без чітких часових закономірностей виникнення (рис. 1).

Мікробіологічне дослідження ранової поверхні засвідчило колонізацію поверхні ран мікроорганізмами роду Staphylococcus (S. epidermidis - 80 \%, S. aureus - 20 \%), кількість яких, виражена в десяткових логарифмах, в основній гру-

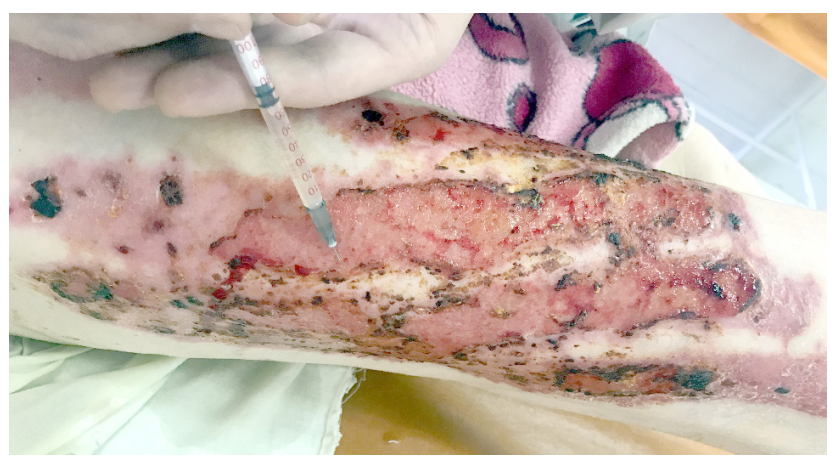

Рис. 1. Пацієнтка К., 60 років, медична карта № 14271, 27 доба з моменту отримання травми. Виконується ін'єкційне введення автологічної плазми, збагаченої тромбоцитами в ділянку ран донорської поверхні, що тривалий час не загоюються. пі досягала $(7,3 \pm 0,55) \mathrm{KУО/мл,} \mathrm{групі} \mathrm{порівняння}$ $(7,6 \pm 0,35) \mathrm{KУО/мл,} \mathrm{що} \mathrm{суттєво} \mathrm{перевищувало} \mathrm{до-}$ пустимий пороговий рівень мікробного числа в рані (lg 5,0 КУО/мл).

На 3 добу після первинного ін'єкційного введення плазми в пацієнтів основної групи встановлено ознаки очищення ран від патологічних нашарувань, зміну грануляційної тканини до насиченого рожевого кольору з еластичною консистенцією, висота якої не перевищувала рівня інтактної шкіри. По краях рани визначалось формування облямівки, а на самій поверхні - острівців епітелізації, що вказувало на активізацію репаративних процесів. Невелика кількість виділення з рани мала переважно серозний вміст, інтенсивність больових відчуттів значно зменшилась, як і площа ранового дефекту до $(181,7 \pm 9,5)$ см $^{2}$ (рис. 2). У хворих групи порівняння у ці ж терміни подібного активного покращення стану рани не визначали, рановий дефект площею $(279,4 \pm 12,1)$ см$^{2}$ залишався вкритим грануляційною тканиною, яка за характеристиками особливо не відрізнялася від вихідних показників. В рані та навколишніх тканинах зберігались ознаки помірного запалення з періодичними больовими відчуттями. 3 поверхні ран виділили $S$. aureus у двох пацієнтів групи порівняння $(\lg (6,6 \pm 0,61) \mathrm{KУО/мл),} \mathrm{в} \mathrm{інших} \mathrm{пацієнтів} \mathrm{-}$ S. epidermidis $(\lg (6,3 \pm 0,16) \mathrm{KУO/мЛ).} \mathrm{В} \mathrm{основній}$ групі рани були колонізовані лише S. epidermidis в кількості $\lg (5,2 \pm 0,16)$ КУО/мл.

Уже на 7 добу у пацієнтів, місцеве лікування яких передбачало використання плазми, на донорських ранах визначали активне розростання епітеліального шару, який покривав майже всю поверхню. В зазначеній ділянці не визначалося ознак активного запалення, суб’єктивні відчуття болю також були відсутні (рис. 3). Рани були коло-

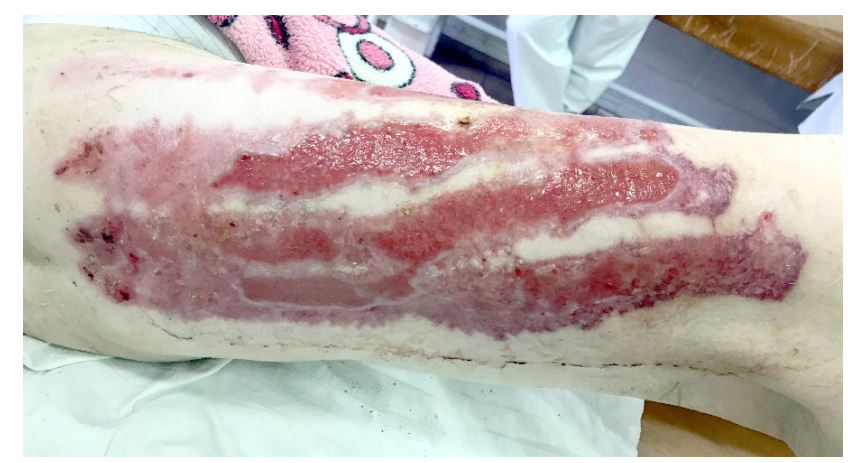

Рис. 2. Пацієнтка К., 60 років, медична карта № 14271, 3 доба після ін’єкційного введення плазми. Рана загоюється зі зменшенням проявів запальної реакції. 


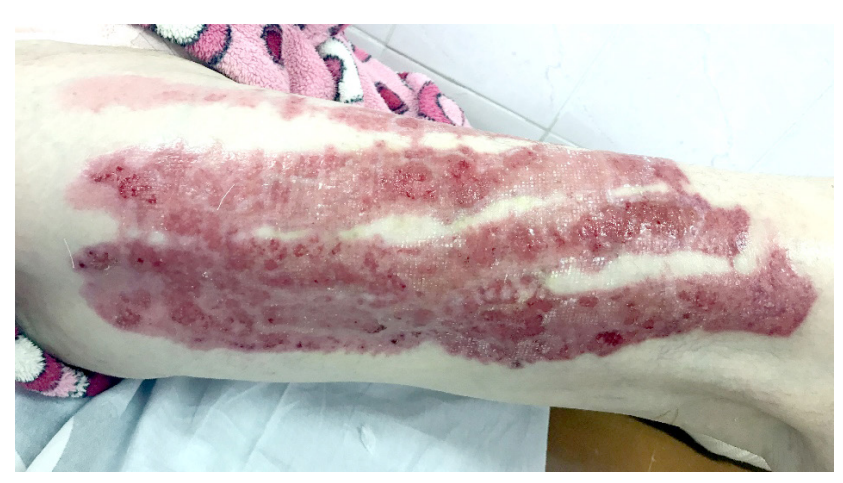

Рис. 3. Пацієнтка К., 60 років, медична карта № 14271, 7 доба після ін’єкційного введення плазми. Спостерігається практично повна епітелізація ранового дефекту.

нізовані лише S. epidermidis $\lg (4,32 \pm 0,76) \mathrm{KУO/мл}$ у 60 \% хворих. Пацієнтам групи порівняння було виконано хірургічне втручання з видаленням надлишкової грануляційної тканини та закриттям гранулюючих ран тонкими перфорованими (коефіцієнт 1:4) трансплантатами шкіри.

Загалом майже повне загоєння ран донорських поверхонь у пацієнтів основної групи визначали на $(9,3 \pm 1,2)$ доби від початку дослідження, що дало можливість скоротити терміни лікування таких пацієнтів до $(37,4 \pm 1,9)$ доби (рис. 4). Незважаючи на дещо вищу травматичність обраного лікування у хворих групи порівняння з формуванням додаткових ран тривалість їхнього загоєння з приживленням автодермотрансплантатів становила $(14,1 \pm 0,9)$ доби, а перебування в стаці-

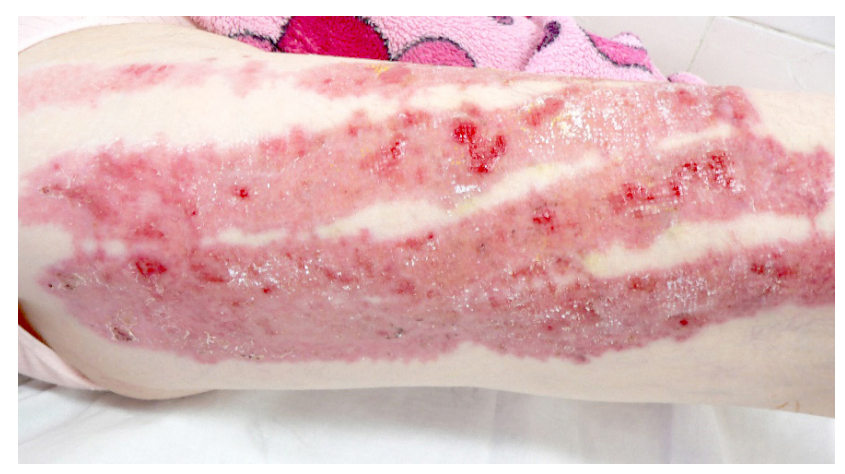

Рис. 4. Пацієнтка К., 60 років, медична карта № 14271, 10 доба після ін’єкційного введення плазми перед виписуванням із стаціонару. Рана повністю загоїлась.

онарі - $(42,5 \pm 2,2)$ доби. Мікробіологічна картина ранової поверхні в основній групі характеризувалась появою бактерій роду Corynebacterium (недифтерійні види) на рівні $\lg (3,2 \pm 0,67) \mathrm{KУО/мл} \mathrm{в}$ усіх хворих. Лише в одному випадку було виділено епідермальний стафілокок, кількість якого не перевищила $\lg$ 3,0 КУО/мл.

Результати вивчення клітинного складу ранового вмісту донорських поверхонь наведено в таблиці 1.

Так, на 1 добу спостереження (27 доба з моменту отримання травми) рановий вміст в обох групах не відрізнявся, а гістологічна картина відповідала здебільшого запальному типу цитограми: переважно домінували нейтрофільні гранулоцити (НГ) на рівні $(85,7 \pm 0,9) \%$ в основній групі та

Таблиця 1. Цитологічна характеристика ранового вмісту донорських поверхонь обстежених Xворих (n = 15)

\begin{tabular}{|c|c|c|c|c|c|c|}
\hline \multirow{3}{*}{ Показники } & \multicolumn{6}{|c|}{ Терміни спостереження } \\
\hline & \multicolumn{2}{|c|}{1 доба } & \multicolumn{2}{|c|}{3 доба } & \multicolumn{2}{|c|}{7 доба } \\
\hline & $\begin{array}{c}\text { основна } \\
\text { група }\end{array}$ & $\begin{array}{c}\text { група } \\
\text { порівняння }\end{array}$ & $\begin{array}{c}\text { основна } \\
\text { група }\end{array}$ & $\begin{array}{c}\text { група } \\
\text { порівняння }\end{array}$ & $\begin{array}{l}\text { основна } \\
\text { група }\end{array}$ & $\begin{array}{c}\text { група } \\
\text { порівняння }\end{array}$ \\
\hline $\begin{array}{l}\text { Нейтрофільні } \\
\text { лейкоцити, \% }\end{array}$ & $85,7 \pm 0,9$ & $87,1 \pm 0,7$ & $70,4 \pm 0,8^{*}$ & $79,3 \pm 0,9$ & $52,7 \pm 0,5^{*}$ & $68,1 \pm 0,7$ \\
\hline $\begin{array}{l}3 \text { них дегенеративні } \\
\text { форми, \% }\end{array}$ & $57,4 \pm 0,6$ & $56,8 \pm 0,8$ & $39,4 \pm 0,6^{*}$ & $52,8 \pm 0,7$ & $13,4 \pm 0,3 *$ & $38,4 \pm 0,5$ \\
\hline Лімфоцити, \% & $5,8 \pm 0,3$ & $5,4 \pm 0,5$ & $7,2 \pm 0,5$ & $6,0 \pm 0,3$ & $8,9 \pm 0,4$ & $7,3 \pm 0,8$ \\
\hline Моноцити, \% & $2,9 \pm 0,2$ & $2,6 \pm 0,3$ & $2,8 \pm 0,1$ & $2,2 \pm 0,2$ & $3,1 \pm 0,2$ & $2,9 \pm 0,2$ \\
\hline Макрофаги, \% & $6,1 \pm 0,4$ & $5,7 \pm 0,2$ & $8,7 \pm 0,3^{*}$ & $6,3 \pm 0,5$ & $12,7 \pm 0,3 *$ & $8,5 \pm 0,4$ \\
\hline Фібробласти, \% & $4,7 \pm 0,3$ & $4,3 \pm 0,2$ & $9,3 \pm 0,7 *$ & $5,1 \pm 0,4$ & $17,8 \pm 0,6^{*}$ & $14,3 \pm 0,9$ \\
\hline
\end{tabular}

Примітка. * - достовірна різниця між відповідними показниками основної групи та групи порівняння $(\mathrm{p} \leq 0,05)$. 
$(87,1 \pm 0,7) \%$ в групі порівняння та їхні дегенеративні форми $(57,4 \pm 0,6) \%$ та $(56,8 \pm 0,8) \%$ відповідно. Незначну кількість визначали мікроорганізми з внутрішньо- і позаклітинним розташуванням.

На 3 добу у пацієнтів основної групи гістологічна картина ранового вмісту характеризувалась стрімким покращенням, яке супроводжувалося зменшенням рівня НГ до $(70,4 \pm 0,8) \%$, їхня дегенеративних форм до $(39,4 \pm 0,6) \%$ на противагу збільшення частки макрофагів $((8,7 \pm 0,3 \%))$ та фібробластів $((9,3 \pm 0,7) \%)$ і відповідало запально-регенераторному типу цитограми. У групі порівняння ці ж показники були достовірно (p $\leq 0,05)$ гірші і становили $(79,3 \pm 0,9) \%,(52,8 \pm$ 0,7) \%, $(6,3 \pm 0,5) \%,(5,1 \pm 0,4) \%$ відповідно, що вказувало на збереження запального типу.

У більш пізніші терміни в рановому матеріалі пацієнтів основної групи й надалі визначалися ознаки активного репаративного процесу, тоді як у групі порівняння зберігалися прояви запальноклітинної реакції. Це підтверджувало інтенсивне підвищення на 7 добу спостереження відносної кількості молодих клітин грануляційної тканини у основній групі пацієнтів (макрофаги - 12,7 $\pm 0,3 \%$, фібробласти - 17,8 $\pm 0,6 \%)$ із зменшенням кількості НГ до $(52,7 \pm 0,5) \%$, що достовірно ( $\leq \leq 0,05)$ відрізнялось від показників, отриманих у пацієнтів $з$ традиційним лише аплікаційним застосуванням антимікробних засобів, а саме $(8,5 \pm$ 0,4) \%, $(14,3 \pm 0,9) \%$ та $(68,1 \pm 0,7) \%$ відповідно.

Таким чином, незважаючи на здавалося б поверхневий характер травми невеликої площі в “стандартних” умовах нанесення, чимало патогенетичних особливостей перебігу ранового процесу донорської поверхні ще недостатньо вивченні і лише загалом характеризуються відсутністю первинної зони некрозу, генералізованими мікросудинними порушеннями, геморагіями тощо. Відновлення втрачених шкірних покривів цієї ділянки при заборі трансплантатів на рівні сітчастого шару дерми можливо за рахунок збереженої епітеліальної вистилки з дереватів шкіри та крайової епітелізації, які можливі лише при відсутності ускладнень [9]. Саме тому запобігання їхньому виникненню залишається одним із основних завдань лікувальної стратегії, яка реалізується на сьогодні шляхом використання різноманітних засобів аплікаційної дії. Існують різні класифікації лікування донорських ран та найбільшого поширення набула пропозиція Б. С. Віхрієва та В. М. Бурмістрова виділити загалом відкриті (напіввідкриті), закриті та хірургічні методи. Використання останніх досить обмежене і рекомендується авторами лише за умов відсутності ознак епітелізації донорських ран впродовж одного місяця і більше. Порівнюючи інші методики, на сьогодні не вдається виокремити найкращий метод, до того ж спостерігається певна суперечливість результатів при їхньому порівнянні. Це підтверджує дискусійність ефективності використання напівпроникної полівінілхлоридної плівки та її аналогів для закриття післяопераційних ран донорської поверхні, які створюють особливе середовище на рановій поверхні. Проведенні численні дослідження дали можливість розвіяти сумніви щодо успішності посттравматичної регенерації тканин в умовах вологого середовища, зменшуючи больові відчуття, прискорюючи загоєння та покращуючи віддалені косметичні результати [10]. Поява сучасних гідроколоїдних пов’язок могло б створити конкуренцію подібним доступним синтетичним плівковим покриттям, проте проведені дослідження не змогли встановити їхніх переконливих переваг, які, до того ж, не порівнювані у ціновому еквіваленті [11]. Незважаючи на це, традиційним стандартом лікування донорських ран залишається використання марлевих пов'язок, просякнутих розчинами антисептиків, багатокомпонентними мазями на водорозчинній основі, кремами, емульсіями або ж використання ранових покриттів, які, незважаючи на простоту використання, супроводжуються високим рівнем інфекційних ускладнень, вчасна діагностика яких може бути ускладнена кровотечами, підвищеною травматизацією, формуванням рубців, уже не кажучи про дискомфорт та виражений біль у післяопераційному періоді [12]. Саме тому на базі опікового відділення ВОКЛ ім. М. І. Пирогова було ініційоване експериментальне клінічне дослідження з вивчення ефективності різних методів місцевого лікування донорських ран. За результатами було встановлено беззаперечні переваги використання принципів вологого середовища, що супроводжувалося скороченням термінів загоєння ран донорської поверхні до $(6,87 \pm 0,14)$ доби (при додатковому використанні струмів низької інтенсивності без зовнішніх джерел живлення до 5,82 \pm 0,05 доби) порівняно 3 традиційним лікуванням, де цей процес тривав $(14,6 \pm 0,41)$ доби [13]. Окрім цього, зниження больового синдрому в 3,37 раза, збільшення об'єму рухів у 3,07 раза, покращення самообслуговування, значно кращі віддалені функціональні та естетичні результати стали підставою для того, щоб із 2011 року повністю відмовитися від використання напіввідкритого лікування цих ран під марлевою серветкою, просякнутою антимікробними засобами на користь використання полівінілхлоридної плівки. Не вдалось лише усунути повною мірою 
розвиток ускладнень, кількість яких зменшилась з 28,7 \% у період 2001-2011 рр. до 6,9 \% за період 2011-2021 рр. і переважно проявлялись інфікуванням, кровотечами з поверхні рани, ростом гіпергрануляцій і супроводжувались тривалим загоєнням $з$ необхідністю виконання додаткових АДП. Можливо, через низьку частоту виникнення подібних ускладнень ця проблема не становила особливого інтересу в дослідників, хоча наслідки від подібних ускладнень можуть бути надсерйозними - становити загрозу життю пацієнта з критичними опіками. В поодиноких доступних літературних джерелах вирішення даної проблеми вбачають у профілактичних діях, які реалізовуються шляхом оптимізації місцевого лікування донорських ран через впровадження простих, ефективних патогенетично-обгрунтованих методів 3 можливістю їх реалізації не лише в умовах спеціалізованих комбустіологічних стаціонарів [14].

Для безпосереднього лікування донорських ран, що тривалий час не загоюються, розроблені показання та обгрунтовано ефективність використання культивованих фібробластів, які за твердженням авторів дають можливість врятувати життя пацієнтів з подібними порушеннями, скоротити терміни лікування і кількість необхідних реконструктивно-відновних хірургічних втручань [15]. Відомі також методи використання суспензії автологічних клітин шкіри у поєднанні з гідроколоїдними пов’язками або ж у вигляді пасти, які дають можливість ще більше підвищити успішність лікування ран донорських поверхонь, зменшуючи ризики розвитку рубцевих ускладнень [16]. На практиці використання таких технологій виявилось складним для відтворення, особливо зважаючи на ціну та необхідність спеціалізованих лабораторій з відповідним матеріальним та кадровим забезпеченням. Саме тому неабиякий інтерес становить значно простіший і доступніший метод стимуляції репаративних процесів, який набуває неабиякої популярності в різних галузях медицини - автологічна плазма, збагачена тромбоцитами. Приготування цього біологічного продукту проводиться з невеликої кількості крові цього ж пацієнта переважно відразу після забору, що підтверджує його абсолютну безпечність. Високий вміст тромбоцитів, факторів росту, хемокінів і цитокінів у такій плазмі робить їі надійним інструментом загоєння ран різної етіології і відновлення тканинних структур, яка, до того ж, проявляє помірну антимікробну та місцеву імуномодулюючу дію [17]. Наразі накопичений достатній досвід використання АПЗТ на різних етапах лікування хворих з опіками, в тому числі результати проспективних рандомізованих контрольованих клінічних досліджень, які підтвердили її ефективність як додаткового методу стимуляції загоєння донорських ран, зменшуючи, до того ж, інтенсивність больових відчуттів у цій ділянці [18].

Проведені дослідження підтвердили, що використання АПЗТ буде доречним і при лікуванні ускладнених ран донорської поверхні, що тривалий час не загоюються. Результати зовнішнього обстеження ран дало можливість встановити позитивний ефект від введення плазми, збагаченої тромбоцитами уже на 3 добу, що проявлялось зміною кольору та структури грануляційної тканини в кращий бік, активним перебігом процесів епітелізації у вигляді острівців на поверхні крайової облямівки світло-рожевого кольору. В подальшому визначали стрімке зменшення розмірів ранового дефекту із майже повним загоєнням на (9,3 \pm $1,2)$ доби після початку введення плазми. Лікування хворих групи порівняння традиційним способом завершувалось повторним виконанням АДП.

Бактеріологічне дослідження ранового вмісту дало можливість встановити значний рівень мікробної колонізації ран в обох групах спостереження $з$ домінуванням грампозитивних монокультур $S$. epidermidis та $S$. aureus, яке динамічно зменшувалось в процесі лікування.

Цитологічна картина ран на початку спостереження була подібна в обох групах і відповідала запальному, а подекуди навіть дегенеративнозапальному типу цитограми. При цьому позитивні зміни клітинного складу із появою юних форм у пацієнтів основної групи відбувались значно швидше з наближенням до запально-регенераторного типу уже на 3 добу спостереження.

Висновки. Отримані результати дали можливість встановити потенційні можливості ін'єкційного використання плазми, збагаченої тромбоцитиами, впливати на процеси загоєння в комплексному лікуванні хворих із донорськими ранами, які тривалий час не загоюються.

Безумовно, для розробки ефективних методів профілактики та лікування ускладнених ран донорської поверхні необхідно продовжувати дослідження в цьому напрямку для встановлення усіх причин виникнення та патогенетичних механізмів перебігу ранового процесу. В будь-якому разі 3 впевненістю можна стверджувати про ряд особливостей ранового процесу при таких патологічних станах, які не відповідають існуючими традиційним уявленнями і потребують подальшої розробки альтернативних шляхів корекції. 


\section{ОРИГІНАЛЬНІ ДОСЛІДЖЕННЯ}

\section{СПИСОК ЛІТЕРАТУРИ}

1. Sibbald R. G. Deep burns: Comparing the developed and developing world / R. G. Sibbald, E. A. Ayello // Advances in Skin \& Wound Care. - 2019. - Vol. 32 (1). - P. 5.

2. Атясов Н. И. Лечение ран донорских участков при свободной кожной пластике у обожжённых / Н. И. Атясов. - Саранск : МГУ. - 1989. - 91 с.

3. Split-thickness skin graft donor site management: a randomized controlled trial comparing polyurethane with calcium alginate dressings / L. Higgins, J. Wasiak, A. Spinks, H. Cleland // Int. Wound J. - 2012. - Vol. 9 (2). - P. 126-131.

4. The application of platelet-rich plasma in the treatment of deep dermal burns: A randomized, double-blind, intra-patient controlled study / R. E. Marck, K. L. Gardien, C. M. Stekelenburg [et al.] // Wound repair and regeneration : official publication of the Wound Healing Society and the European Tissue Repair Society. - 2016. - Vol. 24 (4). - P. 712-720.

5. Platelet-rich plasma for the treatment of tissue infection: Preparation and clinical evaluation // W. Zhang, Y. Guo, M. Kuss [et al.] // Tissue engineering. Part B, Reviews. - 2019. Vol. 25 (3). - P. 225-236.

6. Илюхин Е. А. Точность и воспроизводимость измерения площади фантомных поражений кожи неправильной формы с помощью мобильного приложения LesionMeter / Е. А. Илюхин, В. Л. Булатов, М. И. Гальченко // Флебология. - 2020. T. 14 (4). - C. 266-274.

7. Шелкова Н. Г. Метод кількісного дослідження вмісту бактерій у клінічних матеріалах, що відібрані за допомогою ватного тампону / Н. Г. Шелкова, В. П. Прокопець // Збірник наукових праць співробітників НМАПО ім. П. Л. Шупика. 2008. - T. 17 (2). - С. 698-702.

8. Покровская М. П. Цитология раневого экссудата как показатель процесса заживления раны / М. П. Покровская, М. С. Макаров. - Москва : Медгиз, 1942. - 48 с.

9. Дермальные кисты участвуют в репаративной рененерации эпидермиса у мышей генотипа $\mathrm{Hrhr} / \mathrm{Hrhr} /$ П. К. Головатенко-Абрамов, Е. А. Жиркова, Е. Г. Колокольчикова [и др.] // Онтогенез. - 2010. - Т. 41 (4). - С. 285-291.

10. Brown J. E. An evidence-based review of split-thickness skin graft donor site dressings / J. E. Brown, S. L. Holloway // International Wound Journal. - 2018. - Vol. 15 (6). - P. 1000-1009. 11. The ideal split-thickness skin graft donor-site dressing: a clinical comparative trial of a modified polyurethane dressing and aquacel / U. Dornseifer, D. Lonic, T. I. Gerstung [et al.] // Plastic and Reconstructive Surgery. - 2011. - Vol. 128 (4). P. 918-924.

12. Обоснование одномоментного применения частотно-модулированного сигнала и раневых покрытий в комплексном лечении донорских ран после аутодермопластики / Е. В. Зиновьев, К. Ф. Османов, А. А. Жилин [и др.] // Фундаментальные исследования. - 2013. - № 12-3. - С. 483-485.

13. Поворозник А. Н. Эффективность лечения донорских ран в условиях влажной камеры с использованием биогальванизации / А. Н. Поворозник // Вісник невідкладної і відновної медицини. - 2008. - Т. 9 (3). - С. 326-328.

14. Крайнюков П. Е. Особенности клинической картины и результаты лечения донорских ран после аутодермопластики у пострадавших от ожогов / П. Е. Крайнюков, Е. В. Зиновьев, К. Ф. Османов // Вестник Национального медико-хирургического центра им. Н. И. Пирогова. - 2018. - Т. 13, № 2. - С. 113-117.

15. Аллотрансплантация культивированных фибробластов на незаживающие раны после аутодермопластики / Д. С. Саркисов, Е. В. Глущенко, Ш. Р. Гуруков [и др.] // Бюллетень экспериментальной биологии и медицины. - 1991. - Т. 111 (5). - C. 542-544.

16. Prospective randomized controlled study on clinical effects of autologous skin paste in repairing medium-thickness skin donor site wounds / H. S. Mao, Y. P. Wang, Q. Wang [et al.] // Chinese Journal of Burns. - 2021. - Vol. 37 (3). - P. 232-236.

17. Platelet growth factors from allogeneic platelet-rich plasma for clinical improvement in split-thickness skin graft / A. Sonker, A. Dubey, A. Bhatnagar [et al.] // Asian J. Transfus. Sci. - 2015. - Vol. 9 (2). - P. 155-158.

18. The use of platelet-rich products for skin graft donor site healing: a systematic review and meta-analysis / C. F. Brewer, A. Smith, B. H. Miranda // J. Plast. Surg. Hand Surg. - 2020. Vol. 15. - P. 1-8.

\section{REFERENCES}

1. Sibbald, R.G., \& Ayello, E.A. (2019). Deep burns: Comparing the developed and developing world. Advances in Skin \& Wound Care, 32 (1), 5. Retrieved from: https://doi.org/10.1097/01. ASW.0000550458.48419.d5.

2. Atyasov, N.I. (1989). Lechenie ran donorskikh uchastkov pri svobodnoy kozhnoy plastike u obozhzhennykh [Treatment of donor sites wounds after split thickness grafting in patients with burns]. Saransk: MGU [in Russian].

3. Higgins, L., Wasiak, J., Spinks, A., \& Cleland, H. (2012). Split-thickness skin graft donor site management: a randomized controlled trial comparing polyurethane with calcium alginate dressings. Int. Wound J., 9 (2), 126-131. Retrieved from: https:// doi.org/10.1111/j.1742-481X.2011.00867.x.

4. Marck, R.E., Gardien, K.L., Stekelenburg, C.M., Vehmeijer, M., Baas, D., Tuinebreijer, ... Middelkoop, E. (2016). The application of platelet-rich plasma in the treatment of deep dermal burns: A randomized, double-blind, intra-patient controlled study. Wound repair and regeneration: Official publication of the Wound Healing Society [and] the European Tissue Repair Society, 24 (4), 712-720. Retrieved from: https://doi.org/10.1111/wrr.12443.
5. Zhang, W., Guo, Y., Kuss, M., Shi, W., Aldrich, A. L., Untrauer, ... Duan, B. (2019). Platelet-Rich Plasma for the Treatment of Tissue Infection: Preparation and Clinical Evaluation. Tissue engineering. Part B, Reviews, 25 (3), 225-236. https://doi. org/10.1089/ten.TEB.2018.0309.

6. Ilyukhin, E.A., Bulatov, V.L., Galchenko, M.I. (2020). Tochnost i vosproizvodimost izmereniya ploshchadi fantomnykh porazheniy kozhi nepravilnoy formy s pomoshchyu mobilnogo prilozheniya LesionMeter [Reliability and accuracy of measuring the surface area of phantom skin lesions with Lesion Meter mobile application]. Flebologiya - Phlebology, 14 (4), 266-274. Retrieved from: https://doi.org/10.17116/flebo202014041266 [in Russian].

7. Shelkova, N., \& Prokopets, V. (2008). Metod kilkisnoho doslidzhennia vmistu bakterii u klinichnykh materialakh, shcho vidibrani za dopomohoiu vatnoho tamponu [Quantitative research method of maintenance of bacteria in clinical species which are selected by waddin tampon]. Collection of Scientific Works of Staff Member of P.L. Shupyk NMAPE, 17 (2), 698-702 [in Ukrainian]. 
8. Pokrovskaya, M.P., \& Makarov, M.S. (1942). Tsitologiya ranevogo ekssudata kak pokazatel protsessa zazhivleniya rany [Cytology wound exudate as an indicator of the process of wound healing]. Moscow: Medgiz [in Russian].

9. Golovatenko-Abramova, P.K., Zhirkovab, E.A., Kolokolchikovab, E.G., Bocharovab, V.S., \& Platonova E.S. (2010). Dermalnye kisty uchastvuyut $\mathrm{v}$ reparativnoy regeneratsii epidermisa u myshey genotipa Hrhr/Hrhr [Dermal cysts participate in reparative regeneration of epidermis in Hrhr/Hrhr mice]. Ontogenez Ontogenesis, 41 (4), 285-291 [in Russian].

10. Brown, J.E., \& Holloway, S.L. (2018). An evidence-based review of split-thickness skin graft donor site dressings. International Wound Journal, 15 (6), 1000-1009. Retrieved from: https:// doi.org/10.1111/iwj.12967.

11. Dornseifer, U., Lonic, D., Gerstung, T.I., Herter, F., Fichter, A.M., Holm, C., ... Ninkovic, M. (2011). The ideal splitthickness skin graft donor-site dressing: a clinical comparative trial of a modified polyurethane dressing and aquacel. Plastic and Reconstructive Surgery, 128 (4), 918-924. Retrieved from: https://doi.org/10.1097/PRS.0b013e3182268c02.

12. Zinoviev, E.V., Osmanov, K.F., Zhilin, A.A., Vinogradov, Y.V., \& Almazov, I.A. (2013). Obosnovanie odnomomentnogo primeneniya chastotno-modulirovannogo signala i ranevykh pokrytiy v kompleksnom lechenii donorskikh ran posle autodermoplastiki [The rationale for the use simultaneously frequencymodulated signal and wound coverings in complex treatment of the donor wounds after autodermaplasty]. Fundamentalnye issledovaniya - Fundamental Research, 12-3, 483-485 [in Russian].

13. Povoroznik, A.N. (2008) Effektivnost lecheniya donorskikh ran v usloviyakh vlazhnoy kamery s ispolzovaniem biogalvanizatsii [Efficacy of donor site treatment in a humid chamber using biogalvanisation]. Vestnik neotlozhnoy i vosstanovitelnoy meditsiny - Bulletin of Emergency and Recovery Medicine, 3, 326-328 [in Russian].

14. Kraynyukov, P.E., Zinovev, E.V., \& Osmanov, K.F. (2018). Osobennosti klinicheskoy kartiny i rezultaty lechenia donorskikh ran posle autodermoplastiki u postradavshikh ot ozhogov [Features of the clinical picture and results of treatment of donor wounds after autodermoplasty in victims of burns]. Vestnik nats. med. khirurg. tsentra im. N.N. Pirogova - Bulletin of N. N. Pirogov National Medical and Surgical Center, 13 (2), 113-117. 15. Sarkisov, D.S., Glushchenko, E.V., Gurukov, Sh.R., Morozov, S.S., Tumanov, V.P., \& Berezhkov, N.V. (1991). Allotransplantatsiya kultivirovannykh fibroblastov na nezazhivayushchie rany posle autodermoplastiki [Allotransplantation of cultured fi broblasts on non-healing wounds after autodermatoplas]. Byull. eksp. biol. med. - Bulletin of Experimental and Biological Medicine, 111 (5), 542-544 [in Russian].

16. Mao, H.S., Wang, Y.P., Wang, Q., Jiang, W.Z., Zhan, W.B., Ma, J.Z., \& Qiu, X.G. (2021). [Prospective randomized controlled study on clinical effects of autologous skin paste in repairing medium-thickness skin donor site wounds]. Chinese Journal of Burns, 37 (3), 232-236. Retrieved from: https://doi. org/10.3760/cma.j.cn501120-20200304-00121.

17. Sonker, A., Dubey, A., Bhatnagar, A., \& Chaudhary, R. (2015). Platelet growth factors from allogeneic platelet-rich plasma for clinical improvement in split-thickness skin graft. Asian Journal of Transfusion Science, 9 (2), 155-158. Retrieved from: https://doi.org/10.4103/0973-6247.162712.

18. Brewer, C.F., Smith, A., \& Miranda, B.H. (2020). The use of platelet-rich products for skin graft donor site healing: a systematic review and meta-analysis. Journal of Plastic Surgery and Hand Surgery, 1-8. Advance online publication. Retrieved from: https:// doi.org/10.1080/2000656X.2020.1846544.

Отримано 06.04.2021

Електронна адреса для листування: vinnitsa_opik_17@ukr.net

V. I. NAGAICHUK, R. M. CHORNOPYSHCHUK, S. D. KHIMICH, O. A. NAZARCHUK

M. Pyrohov Vinnytsia National Medical University

\title{
TREATMENT OF PATIENTS WITH DONOR SITE WOUNDS CHARACTERIZED BY PROLONGED HEALING PROCESS
}

\begin{abstract}
The aim of the work: to substantiate the effectiveness of injectable use of platelet-rich plasma in the treatment of donor site wounds with prolonged healing process in patients with deep thermal burns.

Materials and Methods. The study involved 15 patients with IIb-III degree burns with the area of $10-15 \%$ of the body surface. Starting from (27.3 \pm 0.1 ) days after the injury, depending on the chosen method of local treatment, patients were divided into two groups. Dressings applied to 5 patients of the main group, in addition to treatment of the wound surface with $0.02 \%$ decamethoxine solution, provided for daily injection of autologous platelet-rich plasma on the periphery and directly into the donor site wounds for 6-7 days. The remaining agent was applied to the wound defect, which was covered with a double layer gauze napkin impregnated with the same antiseptic and Polyvinyl chloride film with adhesive tapes as fixation, gauze bandage. Local treatment of donor site wounds of 10 patients in the control group was limited to dressings with the use of the same antiseptic solution.

Examination of the patients included visual inspection of the injured area, determination of wound defect area, microbiological and cytological examination of the wound contents.

Results and Discussion. The results of the study allowed to establish positive effect of autologous platelet-rich plasma, already on the $3^{\text {rd }}$ day of observation, manifested by color change, better structure of granulation tissue, active epithelialization processes in the form of islets on the wound surface and growth on the edges, approximation of the cytological picture to the inflammatory-regenerative type. Subsequently, rapid decrease in the size of the wound defect, appearance of new cell forms with almost complete healing by $(9.3 \pm 1.2)$ days after plasma administration was noted in the patients of the main group. Treatment of the patients in the control group by a traditional way eventually led to repeated skin grafting.
\end{abstract}

Key words: burns; donor site wounds; complications; platelet-rich plasma; skin grafting. 


\author{
В. И. НАГАЙЧУК, Р. Н. ЧЕРНОПИЩУК, С. Д. ХИМИЧ, А. А. НАЗАРЧУК
}

Винницкий национальный медицинский университет имени Н. И. Пирогова

\title{
ЛЕЧЕНИЕ БОЛЬНЫХ С ДОНОРСКИМИ РАНАМИ, КОТОРЫЕ ДЛИТЕЛЬНОЕ ВРЕМЯ НЕ ЗАКИВАЮТ
}

Цель работы: обосновать эффективность инъекционного применения плазмы, обогащенной тромбоцитами, при лечении ран донорской поверхности, которые длительное время не заживают у больных с глубокими термическими ожогами.

Материалы и методы. В исследовании приняло участие 15 больных с ожогами пламенем II -III степени, площадью 10-15 \% поверхности тела. Начиная с $(27,3 \pm 0,1)$ суток после получения травмы в зависимости от выбранного местного лечения пациенты были разделены на две группы. У 5 пациентов основной группы перевязки, кроме обработки раневой поверхности 0,02 \% раствором декаметоксина, предусматривали ежедневное в течение 6-7 суток инъекционное введение аутологичной плазмы, обогащенной тромбоцитами, по периферии и непосредственно в область донорских ран. Остаток препарата аппликационно наносился на раневой дефект, который покрывался двухслойной марлевой салфеткой, пропитанной одноименным антисептиком и поливинилхлоридной пленкой с фиксацией лейкопластерными лентами, марлевой повязкой. У 10 пациентов группы сравнения местное лечение донорских ран ограничивалось перевязками с использованием этого же антисептического раствора.

Обследование больных предусматривало визуальный осмотр поврежденного участка, определения площади раневого дефекта, микробиологическое и цитологическое исследование раневого содержимого.

Результаты исследований и их обсуждение. Результаты исследования позволили установить положительный эффект от введения аутологичной плазмы, обогащенной тромбоцитами, уже на 3 сутки наблюдения, что проявлялось изменением цвета, структуры грануляционной ткани в лучшую сторону, активным течением процессов эпителизации в виде появления островков на поверхности раны и роста с краев, приближением цитологической картины в воспалительно-регенераторного типа. В дальнейшем у пациентов основной группы определялось стремительное уменьшение размеров раневого дефекта, появление юных клеточных форм с почти полным его заживлением на $(9,3 \pm 1,2)$ сутки после начала введения плазмы. Лечение больных группы сравнения традиционным способом завершалось выполнением аутодермопластики.

Ключевые слова: ожоги; донорские раны; осложнения; плазма, обогащенная тромбоцитами; аутодермопластика. 